
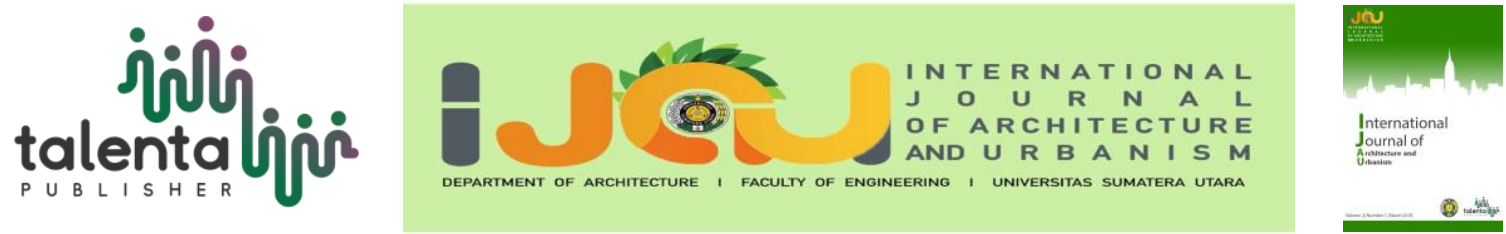

\title{
Architectural Style Application of Mayor Office's and Ria Cinema's Building in Pematangsiantar
}

\author{
Morida Siagian $^{1 *}$, Rumini Manurung ${ }^{1}$ \\ ${ }^{1}$ Department of Architecture, Universitas Sumatera Utara, Medan, Indonesia
}

\begin{abstract}
The development of architecture in Indonesia cannot be separated from foreign countries; we can see from the many forms of buildings in Indonesia that adopted the overseas architectural styles, one of them is Dutch Colonial Architecture Style. Pematangsiantar is one of the city that got influence from Dutch Colonial in architecture. The Building of The Mayor Office and the Ria Cinema is including the building of the colony's historical relics around The H. Adam Malik Park Pematangsiantar that applied The Dutch Colonial Architectural Style. This research reviewed the application of Dutch Colonial Architectural Style in Indonesia in the building of The Mayor Office and Ria Cinema in Pematangsiantar. This research used the descriptive qualitative method that is, the data generated through direct observation of the object research and conduct literature study by studied the results of research and books related to Dutch Colonial Architecture Style in Indonesia. The results showed that the building of The Mayor Office in 1920, Pematangsiantar dominantly applied The Dutch Colonial Architectural Style in Indonesia in Period of 1800s-1902, Ria Cinema Pematangsiantar dominantly applied The Dutch Colonial Architectural Style in Indonesia in Period of 1920s-1940s.
\end{abstract}

Keyword: office, cinema, colonial architecture

\section{Introduction}

During the colonialism period, buildings in Indonesia gained much influence from foreign countries, we can see from the establishment of government buildings, military function buildings, trade functions, educational functions, and recreation functions [9].

Pematangsiantar is one of the city that got influence from Dutch Colonial in architecture. In 1915 the City Pematangsiantar served as the capital afdeling Landschap Simalungun en Karolanden because of its strategic location as a liaison of political, economic interests of the Dutch region Tapanuli, Karo, Simalungun, and lowlands of East Sumatera [4]. Just like other cities in Indonesia, Pematangsiantar City also has the colonial-style architectural heritage that is H. Adam Malik Park. There are two functions as office functions (Mayor Office and Bank

*Corresponding author at: Department of Architecture, Faculty of Engineering, Universitas Sumatera Utara,

Jalan Perpustakaan Gedung J07, Medan 20155, Indonesia

E-mail address: pohontepiair @ gmail.com 
Rakyat Indonesia) and commercial functions (Ria Cinema and Juang 45 Building). The buildings have changed regarding the form since the first built until now.

The Mayor Office and Ria Cinema Pematangsiantar are considered to be examined by the researcher. Because of the existence of heritage buildings increasingly unnoticed even threatened to be destroyed and replaced with new buildings that are more follow the development era. By doing this research, it will further strengthen the evidence that the building is worth preserving as a form of historical relics to remain known in the future.

\section{Literature Review}

Historic buildings are buildings of great importance to history, science and culture [6]. Something that triggers an ongoing curiosity about people with a particular habit that can produce the building [3]. Buildings that have cultural values and historical characteristics so should be protected by the government [7]. We could see from the many forms of buildings in Indonesia that adopted the architectural styles, one of them is Dutch Colonial Architecture Style. The following is the periodization of the Dutch Colonial Architecture Style that developed during the Dutch colonial period in Indonesia according to Helen Jessup. The first, Architectural Style in the 16-1800s, the Dutch Colonial Architecture during this time tended to lose its orientation in traditional buildings in the Netherlands, where, it did not adapt to the local climate and environment (Tabel 1).

Tabel 1. Tabel Characteristics of buildings in the 16th century 1800s

\begin{tabular}{|c|l|l|}
\hline \multirow{2}{*}{ No. } & \multirow{2}{*}{ Element } & \multicolumn{1}{|c|}{ Characteristics of the building } \\
\cline { 3 - 3 } & Plan & $\begin{array}{l}\text { Purwanto and Hasbi (2014) } \\
\text { narrow }\end{array}$ \\
\hline 2 & Roof & Steep roof \\
\hline 3 & Wall & $\begin{array}{l}\text { Dutch-style in front and the end of } \\
\text { walled terrace }\end{array}$ \\
\hline
\end{tabular}

The second, Architectural Style in the 1800s (early 19th century) -1902, formed its architectural style known as The Empire Style is Neo-Classical Architectural Style that hit Europe (especially France) and freely translated [1][2][5]. The result was a colonial-style Dutch East Indies adapted to the local environment, climate, and materials available at the time (Tabel 2).

Tabel 2. Tabel Characteristics of building in the 1800s (early 19th century) - 1902

\begin{tabular}{|c|c|l|l|l|}
\hline \multirow{2}{*}{ No. } & \multirow{2}{*}{ Element } & \multicolumn{3}{|c|}{ Characteristics of the building } \\
\cline { 3 - 5 } & Pandinoto (1994) & \multicolumn{1}{|c|}{$\begin{array}{c}\text { Helen Jessup in } \\
\text { Koeswandi (2013) }\end{array}$} & $\begin{array}{c}\text { Efendi and } \\
\text { Suratminto (2014) }\end{array}$ \\
\hline 1 & $\begin{array}{l}\text { Plan symmetrically } \\
\text { There is a central room }\end{array}$ & $\begin{array}{l}\text { Plan symmetrically } \\
\text { The front and back } \\
\text { porches are open }\end{array}$ & $\begin{array}{l}\text { There are a large } \\
\text { tree and yard }\end{array}$ \\
\hline 2 & Roof & High ceiling & $\begin{array}{l}\text { Shield roof } \\
\text { High ceiling }\end{array}$ & \\
\hline
\end{tabular}




\begin{tabular}{|c|c|l|l|l|}
\hline \multirow{2}{*}{ No. } & \multirow{2}{*}{ Element } & \multicolumn{3}{|c|}{ Characteristics of the building } \\
\cline { 3 - 5 } & $\begin{array}{c}\text { Hall } \\
\text { Color, } \\
\text { door, } \\
\text { window) }\end{array}$ & Thick wall & $\begin{array}{c}\text { Helen Jessup in } \\
\text { Koeswandi (2013) }\end{array}$ & $\begin{array}{c}\text { Efendi and } \\
\text { Suratminto (2014) }\end{array}$ \\
\hline 4 & Column & $\begin{array}{l}\text { Thick wall } \\
\text { The high entrance was } \\
\text { flanked by a large } \\
\text { window }\end{array}$ & $\begin{array}{l}\text { The building is } \\
\text { white }\end{array}$ \\
\hline
\end{tabular}

The third, Architectural Style in the Year 1902-1920an, The next development is the development of Indische Architecture which is a type of residence throughout the Dutch East Indies at that time [10]. The application of the liberals in the Netherlands forced the ethical policy in the colonies. Since then Dutch settlement in Indonesia has spread rapidly (Tabel 3).

Tabel 3. Tabel Characteristics of building in the 1902-1920s

\begin{tabular}{|c|c|l|}
\hline No. & Element & \multicolumn{1}{|c|}{ Characteristics of the building } \\
\cline { 3 - 3 } & Plan & Symmetrical plan one floor \\
\hline 2 & Roof & $\begin{array}{l}\text { Shield roof } \\
\text { There is a gevel or crown on the } \\
\text { front and back porch }\end{array}$ \\
\hline 3 & Column & Rows of Greek-style columns \\
\hline
\end{tabular}

The fourth, Architectural Style in the 1920s-1940s, when the movement of architectural modernism moves in Europe early 20th century, Indonesia became a place of the experiment the emergence of the new architecture (Neues Bauen) [2][8]. In the 1920s-1940s, Dutch architects working in Indonesia experimented with innovations in different building arts from their home country (Tabel 4).

Tabel 4. Tabel Characteristics of building in the 1920s-1940s

\begin{tabular}{|c|c|l|l|}
\hline \multirow{2}{*}{ No. } & \multirow{2}{*}{ Element } & \multicolumn{2}{|c|}{ Characteristics of the building } \\
\cline { 3 - 4 } & Roof & $\begin{array}{l}\text { Handinoto (1996) } \\
\text { There is a horizontal gevel. } \\
\text { There is a tower. }\end{array}$ & $\begin{array}{l}\text { Flat roof } \\
\text { There is a tower that is not } \\
\text { functional. }\end{array}$ \\
\hline 2 & $\begin{array}{c}\text { Wall } \\
\text { color, } \\
\text { window) }\end{array}$ & $\begin{array}{l}\text { The dominant facade is white. } \\
\text { The shape of the checkered } \\
\text { geometry. }\end{array}$ & $\begin{array}{l}\text { The material of concrete } \\
\text { Simple facade, firm horizontal } \\
\text { line, window without ornament. } \\
\text { Dominant white color. }\end{array}$ \\
\hline
\end{tabular}




\section{Methodology}

This research used descriptive qualitative method [11] namely, the data generated through observation directly on the object and conduct literature studies by studying the results of research and books related to the Dutch Colonial Architecture style in Indonesia. The stages of the analysis to find the elements that apply the Dutch Colonial Architecture Style in Indonesia are as follows; Collect data on Dutch Colonial Architecture Style in Indonesia from books and journals. Conduct direct surveys by taking photos and interviews on Ria Cinema Building and Mayor's Office Pematangsiantar. The captured figure was in the form of building elements on the exterior. Data obtained successfully, re-drawn and grouped according to literature review for analysis. The final part is the conclusion of how the application of Dutch Colonial Architecture Style in Indonesia to Mayor's Office and Ria Cinema Pematangsiantar, North Sumatera.

\section{Result and Discussion}

The Mayor's office is located at Jalan Merdeka no. 6, District of West Siantar, Pematangsiantar City. The building was built on January 2, 1920, as the Dutch government office in Pematangsiantar during the Dutch Colonial period. On 6 February to July 29, 1947, was made the Office of the Governor of Sumatera, Mr. Teuku Muhammad Hasan. Currently, the building serves as a government office of Pematangsiantar City. In 2003 there has been an addition that is at the entrance of the building by placing Simalungun cultural ornaments on the roof. The location of Ria Cinema Building is at Jalan Perintis Kemerdekaan No. 1, District West Siantar, Pematangsiantar City. The building was founded in 1953, began operation in 1955. In 2003, the cinema was no longer operational because there were many outstanding pirated VCDs, that so easy to obtain that the number of cinema visitors dropped dramatically. In 2005, this building no longer gets maintenance fund from the government so that the condition of the building more neglected until now.

In this research, Helen Jessup in Koeswandi (2013) grouped the theory periodization development of Dutch Colonial Architecture in Indonesia. Based on the theory, we can study four architectural elements in this research, namely; floor plans, roof (top building), wall (colors, doors, and windows), and columns. The building reviewed is the shape of Mayor's office building in 1920 and Ria Cinema Pematangsiantar building.

\subsection{The Mayor Office's Building}

There are two floors of this building. The first is Administration Room, Regional Secretary Room, Meeting Room, Warehouse, and Toilet, while on the second floor there is Mayor's Room, Mayor's Room, Deputy Mayor Room, Vice Mayor's and Toilet's Guest Room. From the floor plan, we can view on the front of the building shows symmetrical, that is seen from the Administration Room, Lobby and Multipurpose Room on the first floor and viewed from the 
Vice Mayor's Hall, Hall, and Vice Mayor's Living Room on the second floor. We can see from the shape of the roof of the building; the roof divides the building into two equal lengths. From the study, we can find that the building plan of Mayor Office Pematangsiantar was symmetry (Figure 1).

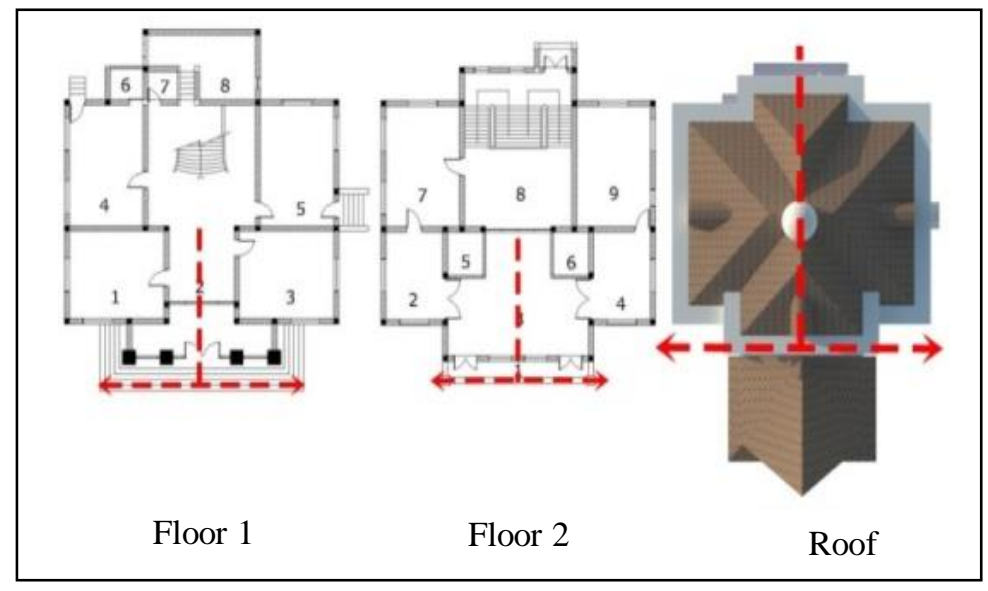

Figure 1. The Symmetry floor 1, 2, and roof of mayor office building Pematangsiantar

The roof used in the building of Mayor's Office Pematangsiantar is the shield roof. In the center of the shield roof, there is a white tubular tower. In the tower section, there is a glassy rectangular section, which surrounds the tower. Overall, the original building of the Mayor's Office Pematangsiantar in 1920 was predominantly white. All the walls of the building are white; we can find other colors on the roof, doors, and windows (Figure 2).

The Mayor's office consists of 15 rooms with a total of 19 doors. The door of the building consists of six single-leaved doors, nine double-leaved doors, and four doors for toilets. The door reviewed is a door that has access to the outside of the building. First is the main of the building, glass material, flanked by glass windows the same size with the height of the door. The second is the exit access door of the Meeting Room, the location is on the left side of the building and similar to the access door out of the rear of the building. This one-leafed door, green, and woody, on top of the door is a small die-glass window for the entry of light. The third is the door on the front and rear balcony of the building, leafy two, wood material, and green. Above it, there is a rectangular window in the horizontal direction, glass material, and on top of that window is another window of glass material with different shapes and sizes (Figure 2).

The window on the building of the Mayor Office of Pematangsiantar totals 25 windows, consisting of 9 one-leafed windows and 16 two-leafed windows. There are eight types of that, old model, shutters, rectangular, high-sized, glass material. Above the window, there is a square-shaped vents glass, and consisting of wooden lattice grille. In the original building plan of the Mayor Office Pematangsiantar in 1920, there are columns on the front of the building. 
The columns consist of four columns with the top end of the arch-shaped column that unites the columns with each other (Figure 2).

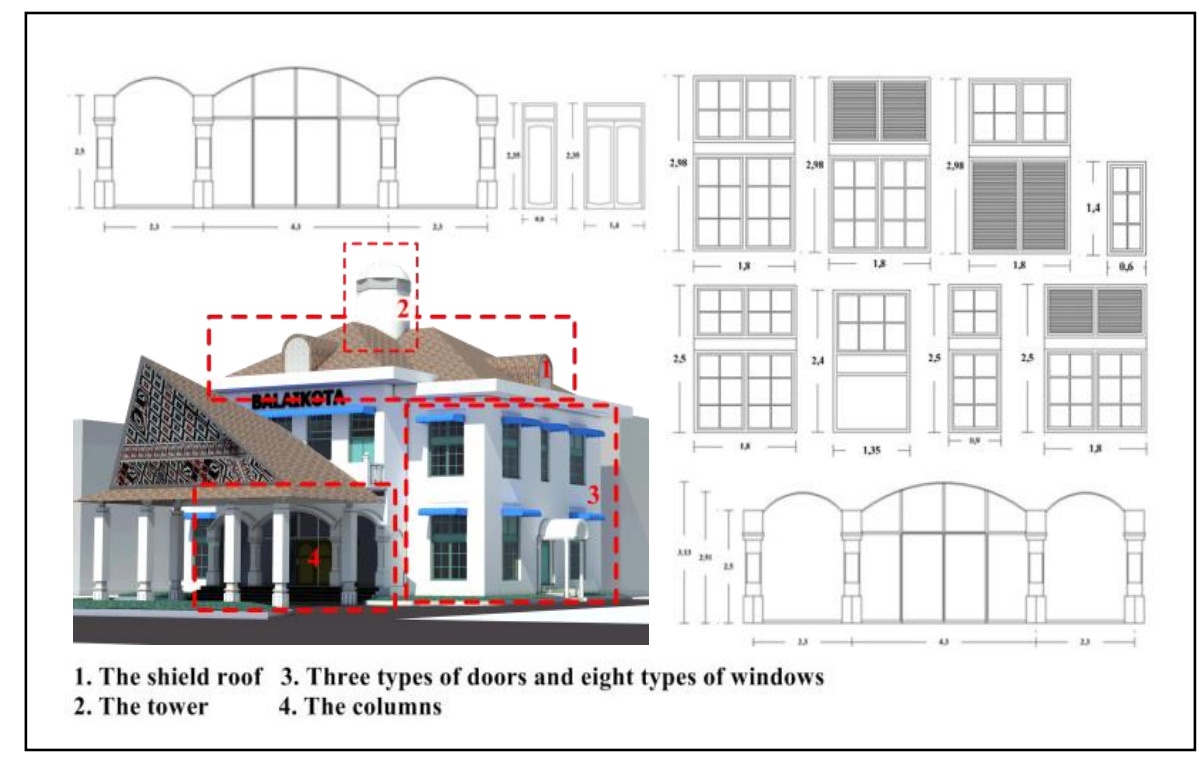

Figure 2. The mayor's office building Pematangsiantar

\subsection{Ria Cinema's Building}

Ria Cinema consists of two floors, the first floor of the building there are several spaces, among others, Lobby, Counters, Mushalla, Waiting Room, Toilet, Spectator Room in the form of Tribune, Warehouse, and Equipment Room. On the second floor, there is only Archive Room Projector and Office Manager. The floor plan of the building is not symmetrical; the floor plan is a modification of the rectangular shape. We can see from the roof of the building; the roof does not divide the building into the same size. From the study obtained the result that the building plan is not symmetry (Figure 3 ).

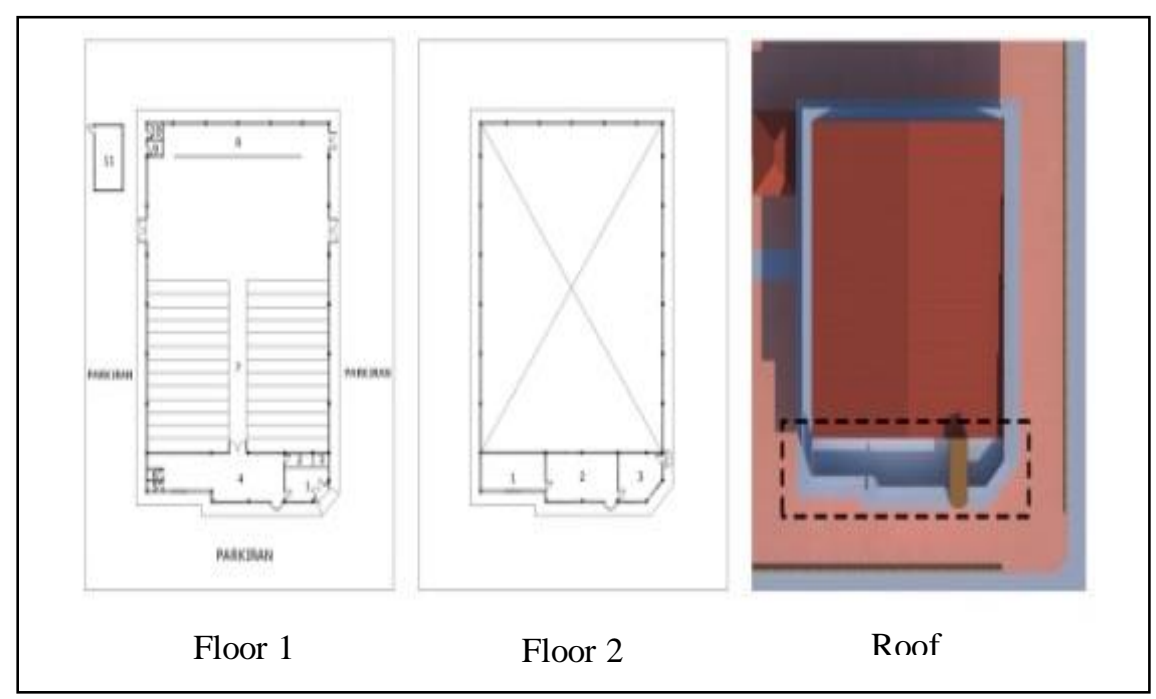

Figure 3. The plan in floor 1,2, and roof of Ria Cinema building Pematangsiantar

The roof on the building of Ria Cinema Pematangsiantar is gable and flat roof. On the second floor of the building, there is an orange-colored, rough-textured tower, with a height that matches the top of a saddle roof. The location of the tower is protruding from the second floor 
towards the front of the building. The tower is not functional, but only a formation of vertical mass. In addition to the tower, the building also has a horizontal gevel in front of the flat roof of the building. Ria Cinema Building Pematangsiantar has a contrasting color that is white and orange. Some of the walls of the building are white, and other parts are orange as the main attraction of the commercial function (Figure 4).

Ria Cinema Pematangsiantar consists of 13 rooms with 15 doors. It consists of 5 double-leaved doors, six single-leaved doors, and four doors for toilets and warehouses. The door reviewed is a door that has access to the outside of the building. First is the main entrance of the building, leaf one, and wood material. The second is the exit access door from the spectator's Tribune Room, located on the left and right side of the building directly into the Parking Area, consisting of two doors. The third is the exit access door of the Archive Room, located on the second floor of the left-hand side of the building, one with a window to the right of the door. The fourth is the access door out of the Equipment Room, located on the left side of the building, two-leafed, and wooden material without ornament (Figure 4).

The window on the Ria Cinema Pematangsiantar building is nine windows, consisting of 1 single leaf window and eight two-leaf. There are four types of the windows, two of them have two-leaf windows, old windows from the beginning of the building was erected, rectangular, and glass material without ornament. Other types of the windows are rectangular, has a standard size, and louver simple type glass (Figure 4). In the Ria Cinema building, there are columns of structures that reside on every wall of the same spaced building. The columns of the building are plain without any ornaments or carvings, the color of each column follows the dominant color of the building that is white (Figure 4).

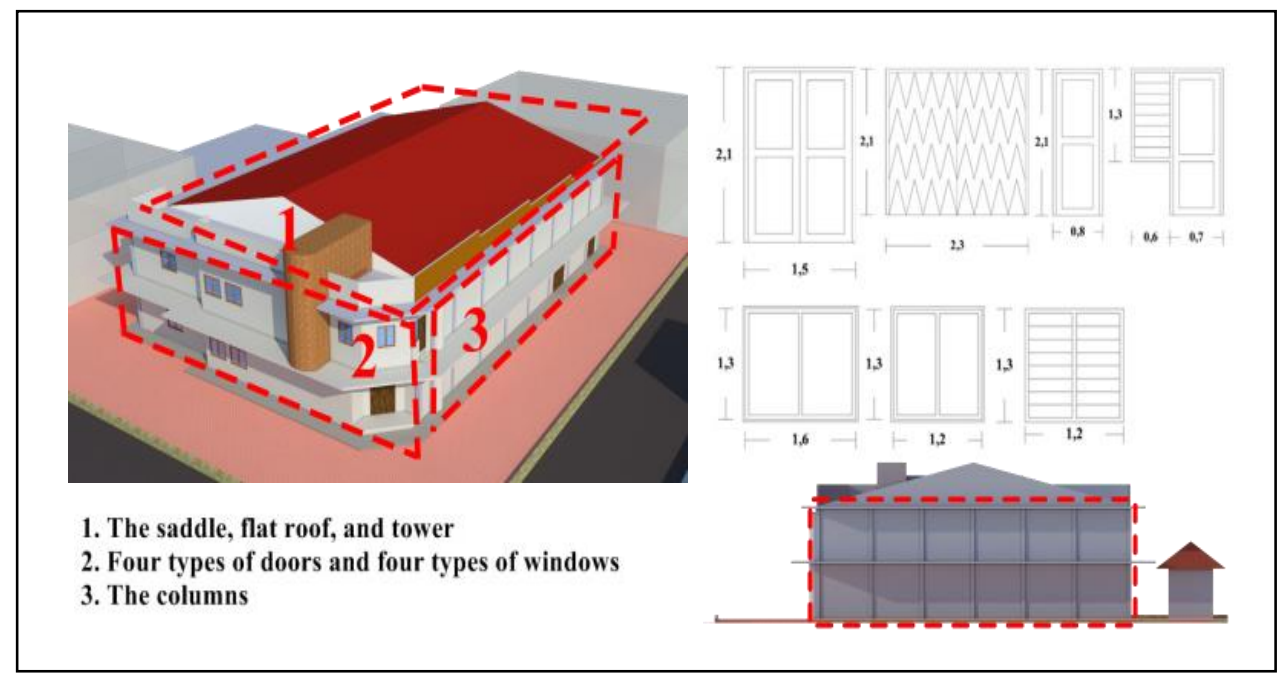

Figure 4. The Ria Cinema's building Pematangsiantar

\section{Conclusion}

The Mayor Office Building of Pematangsiantar applied the architectural style from several periods. Table 5 below is a division that explains the study of architectural elements in the 
building of the Mayor Office Pematangsiantar who applied the Dutch Colonial Architecture Style in Indonesia. Based on the table, it can be concluded that the original building of the Mayor's Office Pematangsiantar 1920 dominantly apply the Dutch Colonial Architecture style in Indonesia in the period of 1800s-1902 (Tabel 5).

Tabel 5. Tabel application of Dutch colonial architecture style in Indonesia at the mayor office Pematangsiantar

\begin{tabular}{|c|l|l|l|}
\hline No. & \multicolumn{1}{|c|}{ Element } & \multicolumn{1}{c|}{ Period } \\
\hline 1 & Plan & Plan symmetry more than one floor & In 1800an-1902 \\
\hline 2 & Roof & $\begin{array}{l}- \text { Shield roof } \\
- \text { There is a tower in the center of the } \\
\text { roof of the building shield. }\end{array}$ & $\begin{array}{l}\text { In 1800an-1902 } \\
\text { In 1920an-1940an }\end{array}$ \\
\hline 3 & $\begin{array}{l}\text { Wall } \\
\text { (color, } \\
\text { door, } \\
\text { and } \\
\text { window) }\end{array}$ & $\begin{array}{l}- \text { The dominant wall is white } \\
- \text { The high entrance is between the } \\
\text { two large windows }\end{array}$ & In 1800an-1902 \\
\hline 4 & Columinant & $\begin{array}{l}\text { It has a row of columns on the front of } \\
\text { the building. }\end{array}$ & $\begin{array}{l}\text { In 1800an-1902 } \\
\text { In 1902-1920an }\end{array}$ \\
\hline
\end{tabular}

Ria Cinema Building Pematangsiantar applied the architectural style from several periods. Table 6 below is a division that explains the study of architectural elements in Ria Cinema building Pematangsiantar had Dutch Colonial Architecture Style in Indonesia. Based on the table, it can be concluded that the dominant Ria Cinema building Pematangsiantar applying Dutch Colonial Architecture Style in Indonesia in the 1920s-1940s Period (Tabel 6).

Tabel 6. Tabel application of Dutch colonial architecture style in Indonesia at the Ria Cinema building Pematangsiantar

\begin{tabular}{|c|l|l|l|}
\hline No. & \multicolumn{1}{|c|}{ Element } & \multicolumn{1}{c|}{ Periode } \\
\hline 1 & Plan & Modified from a rectangular shape & In 1920an-1940an \\
\hline 2 & Roof & $\begin{array}{l}\text { - Flat roof } \\
- \text { A tower is not functional } \\
- \text { There is a horizontal gevel }\end{array}$ & In 1920an-1940an \\
\hline 3 & $\begin{array}{l}\text { Wall } \\
\text { (color, } \\
\text { door, and } \\
\text { window) }\end{array}$ & $\begin{array}{l}\text { - Dominant is white } \\
- \text { The facade is simple, window } \\
\text { without ornament } \\
- \text { The shape of the checkered } \\
\text { geometry building }\end{array}$ & In 1920an-1940an \\
\hline 4 & Column & $\begin{array}{l}\text { There is a structure column on the } \\
\text { building }\end{array}$ & $\begin{array}{l}\text { 16th century } \\
\text { 1800s } \\
\text { In 1920an-1940an }\end{array}$ \\
\hline
\end{tabular}

\section{Acknowledgment}

This research is part of the requirement to obtain a bachelor's degree in Architecture Departement Universitas Sumatera Utara. 


\section{REFERENCES}

[1] J. Efendi and L. Suratminto. Seni Bangunan Neo-Klasik: Indische Empire Style Pada Bangunan Raad Van Justitie Binnen Het Kasteel Batavia di Jakarta. 2014.

[2] Handinoto. Indische Empire Style. Gaya Arsitektur "Tempo Doeloe” yang Sekarang Sudah Mulai Punah. 1994.

[3] R. Hidayati. Cara Pemanfaatan Bangunan Kuno dan Bersejarah Sehingga Layak Menjadi Bangunan Cagar Budaya. Skripsi. Jakarta: Fakultas Teknik Program Studi Arsitektur Universitas Indonesia. 2009.

[4] A. G. Irawan. Kota Pematangsiantar pada Masa Awal Kemerdekaan 1945-1947. Skripsi. Medan: Fakultas Ilmu Budaya Program Studi Sejarah Universitas Sumatera Utara. 2015.

[5] J. A. Koeswandi. Ekspresi Gaya Arsitektur Kolonial pada Desain Interior Gedung Lindeteves Surabaya. 2013.

[6] V. A. Kumurur. Pengaruh Gaya Arsitektur Kolonial Belanda pada Bangunan Bersejarah di Kawasan Manado Kota Lama. Temu Ilmiah IPLBI. 2015.

[7] J. K. Mekarsari. Faktor-faktor yang Mempengaruhi Eksistensi Koridor Heritage Braga Kota Bandung. 2011.

[8] A. D. Nasution. Arsitektur Nieuwe Bouwen di Kawasan Pusat Pasar Medan: Satu Lagi Jejak Sejarah yang Mulai Pudar. 2001.

[9] U. Pawitro. Preservasi-Konservasi Bangunan Bersejarah dan Pengelolaan Kawasan Kota Lama. 2015.

[10] Purwanto \& R. M. Hasbi . Kajian Arsitektur Kolonial Belanda pada Iklim Tropis. 2014.

[11] S. Sinulingga. Metode Penelitian. Sumatera Utara: USU Press. 2011. 